\title{
Organizational Theory in Buddhism
}

SASAKI SHIZUKA 佐々木 閑

Hanazono University

shizuka8@mbox.kyoto-inet.or.jp

Keywords: Śākyamuni, Business Management System (BMS),

Vinaya, samgha

DOI: https://dx.doi.org/10.15239/hijbs.02.02.07

Abstract: What does conceiving of the Vinaya as a religious Business Management System (BMS) illuminate and obscure about the early Buddhist community? This article pursues an answer to this question through a close study of the Buddhist monastic regulations that have sustained the Order for more than 2,500 years. Doing so, the article aims to suggest some of the ways that economic theory and practice can contribute to scholarly understandings of Buddhist tradition past and present. 
bout 2,500 years ago, Saakyamuni, troubled by the amount of
suffering in the world, abandoned his position as a prince and renounced the world, instead embracing a life of religious practices aimed at true happiness. Perceiving that the cause of his suffering was the defilements in his heart, he believed that only ascetic training could completely destroy these defilements and help him attain enlightenment under the Bodhi tree.

This is the story of Śākyamuni's early life. His human nature has been described therein as completely selfish. When one strives with all one's might to destroy the source of one's own suffering, it may seem that there is no room to consider how to benefit others. During this time, Saakyamuni continued to walk on the path of self-salvation with utmost determination. We could compare his efforts to that of a person suffering from an incurable disease desperately looking for a cure. Therefore, his 'enlightenment under the Bodhi tree' signifies a completion of treatment and the complete healing of a diseased mind.

Once he attained enlightenment under the Bodhi tree, compassion for others awakened in Śăkyamuni's heart. He began preaching the path to enlightenment that he had discovered through great effort, seeking to save others who were troubled by the same suffering as him. The famous episode of Brahmā's entreaty expresses this change of heart in an interesting way. ${ }^{1}$

Śākyamuni, his compassionate heart thus awakened, dedicated the second half of his life to the salvation of others. He accepted those who gathered to hear his teachings as his disciples and, by educating them with kindness, sought to liberate them from suffering. In this way, a large group of practitioners gathered, with Śàkyamuni as their leader. This is the essence of Buddhism: an organized religion formed by those who considered deliverance from suffering the purpose of their lives and who pursued this goal with utmost effort. ${ }^{2}$

1 For example, $V \mathrm{I}, 4$. The documents containing this episode are presented comprehensively in Nakamura, Nakamura Hajime senshü, 457.

2 See Satō, Genshi bukkyō kyōdan; Hirakawa, Genshi bukkyō, for the form of management of the organization. 
Guiding a great number of disciples imposed an enormous responsibility on Śākyamuni. He needed to manage the group effectively in order to enable these disciples to properly spend their days absorbed in practice and progress towards true comfort—Śàkyamuni superbly fulfilled this responsibility. He developed and implemented a cohesive organization to enable this large group of disciples to smoothly and successfully traverse the path of Buddhist practices. This type of organization, designed by Śākyamuni or the Buddha for use in training disciples, is called the samgha. The samgha has continued unchanged for 2,500 years, mainly in the predominantly Buddhist countries of Sri Lanka and Southeast Asia. ${ }^{3}$

Even if we were to look globally, it is unlikely that we would find any other example of an organization operating in the same way for 2,500 years. It is difficult for most corporations to maintain their existence for even one hundred years, but the samgha has persisted in many countries in East Asia for 2,500 years, even though this organization has no president or board of directors and consists solely of a gathering of practitioners. How did the Buddhist samgha survive for such a long time without being crushed by changing times and social upheavals? Why does it possess such sustainability? We will discuss this matter in the following paragraphs. ${ }^{4}$

The members who gather in the samgha (monks/nuns) are attracted by the teachings of Śākyamuni and decide themselves to come together. Therefore, the samgha is a collective body of people who wish to live doing only what they love to do-that is, Buddhist practices. People who join the samgha and engage in Buddhist practices are devote themselves to training every day and live a content life arising from their sense of daily improvement. By renouncing worldly desires, it is possible to live a life during which one is free to do what one likes. ${ }^{5}$

3 Samghas of nuns do not exist in the Buddhist countries of Southeast Asia such as Thailand, due primarily to the political upheaval in Sri Lanka about 1,000 years ago. This is the biggest drawback in the world of Theravāda Buddhism, but there are no signs of a solution. See Sasaki, 'A Problem in the Re-establishment'; Seeger, 'The Bhikkhuni- ordination controversy in Thailand'.

4 Sasaki, Shukke; Sasaki, Ritsu ni manabu ikikata no chi-e; Sasaki, Ritsu. 
This kind of renunciation does not entail one throwing away one's connections with everyday life and becoming a recluse. In this world, there are times when people who cannot live according to worldly values and who wish to pursue another purpose in life gather and form a special society, distinct from the rest of the world like an island. The act of joining such an island society because one is drawn to its unique values constitutes 'renunciation'. A layman, who is attracted to the teachings of Śākyamuni and becomes a member of the samgha constitutes a typical case of renunciation.

From a worldly perspective, the life of a person who has renounced the world, no longer works, and only does what he loves appears attractive. Naturally, however, this kind of a life comes with its own risks. One such risk is the possibility that one will not be able to obtain food. By giving up work, renouncing the secular world, and devoting oneself wholly to Buddhist practices, one has no way to obtain the necessities of life. Nor does one have a place to live. Ever since Śākyamuni's time, all samgha members have had no definite address and are unemployed. ${ }^{6}$

Without a solution to this problem, all these members would starve to death. However, Śākyamuni presented a solution. He said, 'Bow your head to those who are working in the world, accept the sharing of things that are in surplus and that others do not need in daily life, and live by it'. In other words, the Buddha advocated mendicancy.

Śăkyamuni required his disciples to practice a thoroughly mendicant way of living, declaring that 'one must never eat any food except that which is kindly put by others in the alms bowl'. Therefore, the Buddhist samgha survives by relying completely on the benefits received from general society - that is, offerings. ${ }^{7}$

Therefore, the most important element for operating the samgha successfully is a consistent supply of offerings. As this is the sole source of sustenance, the samgha collapses when offerings are cut off.

\footnotetext{
5 For example, 'Sāmaññaphala-sutta' ( $D$ I, 47a).

6 Sasaki, 'Muichimotsu'.

7 V 4, 90.
} 
This would mean the disappearance of Buddhism in that country or region. What conditions cause such a situation to occur?

As the offerings consist of food and goods that other members of society offer of their own benevolence, offerings are not a kind of commercial activity. Since the monks of the samgha are not performing any work, they should not, in principle, be rewarded. However, some parts of society regard monks to have their own kind of value. This value may consist of, for example, respect for the monk who makes sincere efforts in his practice or empathy for one who dedicates his life to such noble activities-a way of life that the givers themselves cannot follow even if they may wish to. The giver may think that by offering alms to a great person, the giver could accumulate good karma and consequently receive good fortune in the distant future. These are the typical feelings that motivate people to supply offerings.

This observation indicates that when people do not perceive loftier values in monks, they do not supply offerings to them. For example, when monks and nuns are ill-behaved or evil-hearted, pursue worldly values, do not conduct ascetic practices seriously, or appear to live for the purpose of receiving offerings become the object of people's contempt, and they can no longer receive offerings. ${ }^{8}$

If this phenomenon of denying offerings was limited only to an individual monk, it would not be particularly problematic and would be solved when the monk in question took personal responsibility for his sustenance and abandoned the ascetic way of life. However, Buddhism is a collectivist religion in which the samgha

8 The Vinaya contains many prohibitions, but the reason given for all of them is 'to stabilize the samgha and to deepen the faith of the believers' (Hirakawa, Ritsuzo , 308-12). 'On account of this, monks, I will make known the course of training for monks, founded on ten reasons: for the excellence of the Order, for the comfort of the Order, for the restraint of evil-minded men, for the ease of well-behaved monks, for the restraint of the cankers belonging to the here and now, for the combating of the cankers belonging to other worlds, for the benefit of non-believers, for the increase in the number of believers, for establishing dhamma indeed, for following the rules of restraint. Thus, monks, this course of training should be set forth' (Horner, Book of the Discipline, 37-38). 
functions as one unit, so the problem does not end there. When even a single member of the samgha commits an act that is frowned upon by society, the reputation of the whole samgha is tainted, trust disappears, and offerings to the whole samgha stop. Therefore, the samgha must be careful to ensure that it does not have even a single member whom society views unfavorably. ${ }^{9}$

To avoid this risk of social disfavor, the samgha needs to set rules for living a minimalist life, in the form of discipline called the Vinaya that the samgha imposes on all its members. The Vinaya contains hundreds of regulations that prescribe actions that members of the samgha must or must not perform. By following these regulations, the members become capable of demonstrating themselves as monks who are suitable and worthy of receiving offerings. ${ }^{10}$

Because the regulations in the Vinaya do not aim to raise the level of individual monks as practitioners but instead protect the samgha's reputation, breaking the regulations means inflicting damage on the samgha. For example, if a monk kills someone, people who hear about the act may conclude that 'Buddhist monks usually have a serious face but are really wicked persons who kill people. There is no value in offerings alms to such persons'. As a result, they would stop giving offerings. Here, the samgha punishes monks based on regulations in the Vinaya, which call for the permanent expulsion of a murderer. ${ }^{11}$ Moreover, such an expulsion does not apply only to the

9 For example, the Vinaya contains a regulation that states, 'monks/nuns should not engage in worldly plays in association with lay people'. If a monk/ nun has many admirers, becomes carried away by the invitations from these admirers, and makes merry with them by singing, dancing or other recreation, the entire samgha is perceived as 'a gathering of fallen, fake renouncers of the world'. Therefore, this regulation is aimed at averting public criticism. $V$ 2, 9-13; 2, 179-18; 3, 179-86 (Horner, Book of the Discipline, 314-29).

10 Sasaki, Shukke.

11 Beyond the Vinaya, sîla (or morality) was established in order to enhance the level of training of each monk/nun. As the regulations of the Vinaya have been established to protect the samgha, any monk or nun who breaks these rules is punished as someone who puts the samgha at risk. This is the same concept as 
particular local samgha; rather, the violator is deprived of the right to be a practitioner and cannot become a member of any samgha as a Buddhist monk again. ${ }^{12}$ In this way, the samgha's complete regulation of its members' behavior through its own comprehensive law, the Vinaya, becomes a key source of public trust. In other words, it is important to display to general society that the samgha has a self-purification mechanism.

The principles explained above are the basic ones that enable the samgha to survive in society. While being supported by offerings from the general public, the samgha aims to realize a life dedicated to the pursuit of doing only what one wants to do. For this purpose, it has established its own law, the Vinaya, and by observing that law, it seeks to maintain harmonious relations with broader society. Of course, what has been described here is only the ideal form of the samgha. There is no guarantee that the samgha that actually existed in ancient India was managed in the pure form depicted here. ${ }^{13} \mathrm{Nev}$ ertheless, if we consider the samgha's 2,500 years of survival since the establishment of Buddhism, we can see that despite various alternations, its basic philosophy has been preserved intact.

The Vinaya contains considerable wisdom that contributed to the samgha's long-term sustainability. Examples include the following (see Appendix I for more details): (1) the seniority-based criterion for

the law of a state. In contrast, sîla consists of moral regulations to enhance the level of the individual renouncer's humanity, and breaking these regulations has no impact on anyone other than the individual who broke it. The result of breaking silla results only in a personal consequence, namely, the corruption of the humanity of the concerned individual. Therefore, no penalties are associated with síla. This is equivalent to the function of morality and ethics in general society. Monks and nuns follow both the Vinaya rules and silla.

12 How the exiled monk is punished by the laws of society thereafter is a matter that does not concern the samgha. This punishment depends on the social power present at that time.

13 On practical aspects of the management of the samgha, see the various studies by Gregory Schopen. Schopen, Bones; Schopen, Buddhist Monks; Schopen, Buddhist Nuns. 
the samgha's hierarchy; (2) an emphasis on education; (3) the mutual aid system; (4) open sharing of information with society in general; (5) severe punishment for false activity reports; and (6) a complete rule of law in which the Vinaya carries greater authority than the words of any member.

The management-related regulations in the Vinaya are ideally designed to ensure the survival of this island society comprised of people who share a unique sense of values different from worldly values and whose efforts to pursue the purpose of life require the support of offerings from the broader society.

Having examined the factors that contribute to the sustainability of the samgha, let us now consider organizations in modern society that operate similar to Buddhism. We will take the world of scientists as a representative example. I am referring here not to applied scientists involved in developing technology, but pure scientists, the driving force of intellectual curiosity that seeks to unravel scientific truth.

Although there are differences in the level of achievement among people living in this scientific world, these people's aim is not, in principle, to fulfill worldly desires, but rather to unravel some kind of scientific truth. They have become scientists in order to accomplish their purpose of life, namely, scientific research. Their research is not intended to be practically useful to people, and most of it has no direct applicability. One example of this research is the scientific study of the Big Bang. Therefore, no direct reward from society is given for such research. However, funds provided by the goodwill of society-in other words, offerings-support this research-oriented life. If we view the world of scientists as one in which people live life with the purpose of searching for truth and are supported by offerings from the general society, then its basic structure is the same as that of Buddhism. A summary of relevant parallels follows:

1. Scientists, whose highest goal is the search for truth, do not have the capacity of production.

2. Therefore, the funds and materials needed for scientists to make a living and to maintain their research activities depend on offerings from general society. 
3. For scientists to receive offerings from general society, it is important that they remain respectable to the society. The most important condition is to conduct research activities sincerely and without falsification.

4. To show general society that the world of scientists is trustworthy, scientists themselves must establish strict rules and abide by them. This collection of rules corresponds to the Vinaya of the samgha. Moreover, strict punishments must be implemented in accordance with these regulations.

5. For the scientific world to receive offerings on a permanent basis and acquire new members, the meaning of its activities must be publicized to the general society in an easy-to-understand manner. This corresponds to preaching in Buddhism.

If we accept the idea that the management philosophy of the samgha can be applied to the world of scientists living in modern society, then it follows that these principles can also be generalized to other sectors of society with a management structure similar to that of the world of scientists. For example, the worlds of statesmen and artists or that of special projects established to achieve a specific ideal (even if carried out in a for-profit corporate setting) possess aspects akin to the renunciation of the secular world. The legal system known as the Vinaya, established 2,500 years ago, and the organization called the samgha, managed by this legal system, have great value even in modern times as valuable guidance for those who wish to live a renunciant life, a life that cannot be satisfied by worldly values. ${ }^{14}$

14 An example of a recent scandal in the scientific world in Japan is as follows: In 2014, Haruko Obokata, a visiting scholar at Riken, the Institute of Physical and Chemical Research, reported that she had discovered a way to initialize somatic cells by external stimulation (STAP cells). This finding was reported worldwide as a discovery worthy of a Nobel Prize. Her findings were published in the journal Nature, and the reputation of Riken and of Japanese science rose. However, two months later, a number of fraudulent activities were discovered in the research, and it was revealed that the research results were a fabrication with no factual basis. Nevertheless, Riken did not initially exhibit a critical stance toward 


\section{Conclusion}

When the term 'renunciation' is usually used in the field of religion, it tends to be viewed as a religious act. However, in practice, the act of renunciation is not restricted to the religious context; rather, it is observed widely within general society. People who share unique values and have a perspective different from that of worldly desires - that is, people who do not agree that the purpose of life is to simply achieve material comforts-form an organization to achieve these values and carry out activities designed to pursue their goals while receiving support from external society. All such situations are renunciations in certain ways. Buddhism is also one of many such renunciate societies. As mentioned above, the world of scientists is a typical realm of renunciation, as are the world of statesmen, the world of artists, the world of social activists, and groups of employees seeking a purpose for life through special corporate projects.

Although the word 'renunciation' is used here, clearly there are variations as to what portion of one's life is lived in renunciation and what part is still lived for worldly desires. For members of the Buddhist samgha who abandon all productive activities and devote themselves completely to ascetic practices, the degree of renunciation is one hundred percent. For those who spend their weekdays doing regular paid work in a firm or company and devote their weekends to pure scientific or artistic pursuits, the degree of renunciation might be twenty or thirty percent.

Therefore, there are multiple patterns of renunciation. What they share in common is that, in these societies, the renunciants have their own unique perspective of the world and are not caught up in worldly desires. This separation gives them the power to move beyond a

Obokata and continued to avoid taking responsibility for the scandal. As a result, public trust not only in Obokata but in Riken itself declined, and the situation became sufficiently grave that some people proposed shutting down the Riken laboratory. Eventually, Riken took a somewhat ambiguous position of 'equivalent to disciplinary dismissal' toward Obokata, who had already voluntarily resigned. At this time, the scandal remains shrouded in ambiguity. 
fixed sense of values and create a totally new philosophy and culture. Renunciants, at first glance, do not seem to contribute anything to society. However, it is precisely here that their power to transform society from the grassroots level resides. It is important to grasp this principle of social transformation and, therefore, to aim at building a society that suitably protects and nurtures renunciants. To this end, the work of extracting the wisdom of organizational management contained in the Vinaya and reinterpreting it in a form that can be applied to modern society is indispensable.

Needless to say, it is also essential for the many researchers and students who have gathered for this conference, and who now have the awareness that they too are living a life of renunciation, to protect the ideal of renunciants. 


\section{Appendix I}

The Six examples Cited in the Text

1. The ranking of the members of the samgha is determined solely by how long each one has been a monk or nun. Their humanity or level of progress in Buddhist practices is not considered at all. Because the ranking is based solely on seniority, the motivation to seek to outperform others and rise to a higher rank does not emerge. This approach prevents power struggles within the samgha.

2. Emphasis on education: When one becomes a member of the samgha, he receives a mentor called an upādhyāya. The upādbyāya educates the new monks as his disciples day and night for at least five years and must teach them everything: from the regulations of the Vinaya to the teachings of the Buddha and the ways of practicing meditation. In return, the disciple is responsible for taking personal care of the upādbyaya and is obliged to do various chores. This system enables the teachings of the Buddha to be continually propagated within the samgha across generations.

3. The mutual aid system: The education system in (2) also establishes a relationship of mutual aid between the upādhyàya and the disciple. When difficulties due to disease or old age arise, the disciple is responsible for supporting the upādbyāya, and vice versa. This creates an ongoing internal support system for people who have renounced family life in the secular world.

4. Open sharing of information: For the samgha to continuously receive offerings from the surrounding society, it must be trusted by society. One essential requirement for gaining this trust is openness of activity, to demonstrate to the public that the monks and nuns are conducting Buddhist practices sincerely. For this purpose, the samgha residence is, as a rule, open all hours, and members of the general public, irrespective of whether they are believers or not, can enter the samgha 
at any time. Of course, to prevent entry by burglars, there are times when the gates are closed, but trustworthy visitors may enter at whatever time they wish.

5. Severe punishment for false activity reports: One of the most serious sins in the Vinaya is described as follows: 'When the lie of a person who says that he is 'enlightened,' knowing that he is not, is revealed, he is permanently expelled from the samgha' (Pärajizka no. 4). Why is this one of the greatest sins? It is because when one lies in this way, many offerings are received from lay believers who believed the lie. These are, so to speak, offerings collected through fraudulent activity, and when the lie is revealed, the credibility of the whole samgha is severely damaged. However, if the person is mistakenly convinced that he is 'enlightened' and realizes his mistake later and confesses, he is considered innocent, since this is not a deliberate act of fraud.

6. Complete rule of law: As noted above, there is a strict relationship between masters and disciples, but the regulations of the Vinaya are placed at a higher level than the master-disciple relationship. Therefore, a disciple must not obey an order from a master if it is not in accordance with the regulations of the Vinaya. The regulations in the Vinaya carry the highest level of authority. By adopting such a complete rule of law, the samgha can prevent being swayed by the arbitrary policies of a particular person. This is also one of the key factors in ensuring the sustainability of the samgha. 


\section{Bibliography}

Abbreviations

$D$

Dighanikāya. See Bibliography, Primary Sources, Dighanikāya.

$V \quad$ Vinayapitaka. See Bibliography, Primary Sources, Vinaya-Pitakam.

\section{Primary Sources}

Dighanikāya. Edited by T. W. Rhys Davids and J. Estlin Carpenter. London: Pali Text Society London, 1890-1911.

Vinaya-Pitakam. Edited by H. Oldenberg. London: Williams and Norgate, 1879-1883 (reprinted by the Pali Text Society).

\section{Secondary Sources}

Hirakawa Akira 平川彰. Genshi bukkyō no kenkyū, kyōdan soshiki no genkei 原始仏教の研究一教団組織の原形 [A Study on Early Buddhism: The Original Form of Monastic Communities]. Tokyo: Sanki-bō busshorin 山喜房佛書林, 1964.

- - - Ritsuzō no kenkyū 律蔵の研究 [A Study of the Vinayapitaka]. Tokyo: Sanki-bō busshorin 山喜房佛書林, 1960.

Horner, I. B. The Book of the Discipline, Vol. I. Bristol: Pali Text Society, 1938.

Nakamura Hajime 中村元. Ketteiban Nakamura Hajime senshū, gōtama budda I 決定版中村元選集 ゴータマ・ブッダ [Selected Collection of Nakamura Hajime, I]. Tokyo: Shunjū sha 春秋社, 1992.

Sasaki Shizuka 佐々木 閑. 'Muichimotsu to jikatsu no hōki' 無一物 と自活の放棄 [Renunciation of Possessions and Renunciation of Self-support]. Indo tetsugaku bukkyoggaku 印度哲学仏教学 [Hokkaido Journal of Indological and Buddhist Studies] 15 (2000): 21-34.

- - - 'A Problem in the Re-establishment of the Bhikkhunī Sangha in Modern Theravāda Buddhism'. The Eastern Buddhist 
36, no. 1/2 (2004): 184-91.

———. Ritsu ni manabu ikikata no chi-e「律」に学ぶ生き方の智慧

[Wisdom to Live Learned from the Buddhist Discipline]. Tokyo:

Shinchōsha 新潮社, 2011.

_- - Shukke towa nanika 出家とはなにか [What is the Buddhist

Ordination]. Tokyo: Daizō shuppan 大藏出版, 1999.

- - - Shukketeki jinsei no susume 出家的人生のすすめ

[Encouragement for the 'Renunciant' Life]. Tokyo: Shūeisha 集

英社, 2015.

Satō Mitsuo 佐藤密雄. Genshi bukkyō kyōdan no kenkyū 原始仏教教

団の研究 [A Study of the Early Buddhist Order in the Vinaya

Pițaka]. Tokyo: Sanki-bō busshorin 山喜房佛書林, 1963.

Schopen, Gregory. Bones, Stones, and Buddhist Monks. Honolulu:

University of Hawai'i Press, 1967.

-_- Buddhist Monks and Business Matters, Still More Papers on

Monastic Buddhism in India. Honolulu: University of Hawai'i

Press, 2004.

-_- Buddhist Nuns, Monks, and Other Worldly Matters: Recent

Papers on Monastic Buddhism in India. Honolulu: University of Hawai'i Press, 2014.

Seeger, Martin. 'The Bhikkhuni-ordination controversy in Thailand'. Journal of the International Association of Buddhist Studies 29, no. 1 (2006): 155-83. 